\title{
INTERACTION BETWEEN VISITING BEES (HYMENOPTERA, APOIDEA) AND FLOWERS OF Ludwigia elegans (CAMB.) HARA (ONAGRACEAE) DURING THE YEAR IN TWO DIFFERENT AREAS IN SÃO PAULO, BRAZIL
}

\author{
GIMENES, M. \\ Departamento de Ciências Biológicas, Universidade Estadual de Feira de Santana, BR 116, km 3, \\ CEP 44031-460, Feira de Santana, BA, Brazil \\ Correspondence to: Miriam Gimenes, Departamento de Ciências Biológicas, Universidade Estadual de Feira de \\ Santana, BR 116, km 3, CEP 44031-460, Feira de Santana, BA, Brazil, e-mail: mgimenes@uefs.br \\ Received August 20, 2002 - Accepted December 2, 2002 - Distributed November 30, 2003
}

(With 3 figures)

\begin{abstract}
This study was designed to characterize the interactions between Ludwigia elegans flowers and visiting bees during two years in two areas $200 \mathrm{~km}$ apart, at the same latitude (approximately 22 $48^{\circ} \mathrm{S}$ ) but at different altitudes (Alumínio, $600 \mathrm{~m}$, and Campos do Jordão, $1500 \mathrm{~m}$ ), in the State of São Paulo, Brazil. As these flowers open simultaneously in the morning and lose their petals by sunset, interaction with bees occurs only during the photophase. Flowers of $L$. elegans were mainly visited by bees, the most frequent species being: Tetraglossula anthracina (Michener, 1989) (Colletidae), Rhophitulus sp. (Andrenidae), and Pseudagapostemon spp. (Halictidae), all considered specialized bees for collecting pollen and nectar from these flowers, as well as the generalist bee Apis mellifera Linnaeus, 1758 (Apidae). The specialist bees were temporally adjusted to the opening schedule of the flower, which occurs primarily in the morning, but shows a circannual variation. T. anthracina appears in both study areas, but only between December and April. The annual activity patterns of these specialist bees are synchronized to the phenology of L. elegans. Photoperiod and temperature cycles are suggested as the main synchronizers of both bees and plants.
\end{abstract}

Key words: photoperiod, biological rhythm, Tetraglossula, Pseudagapostemon, Rhophitulus.

\section{RESUMO}

\section{Interações entre as abelhas visitantes (Hymenoptera, Apoidea) e as flores de Ludwigia elegans (Camb.) Hara (Onagraceae) durante o ano em duas áreas diferentes em São Paulo, Brazil}

Este estudo foi proposto para caracterizar as interações entre as flores de Ludwigia elegans e as abelhas visitantes durante dois anos, em duas áreas distantes $200 \mathrm{~km}$ entre si, na mesma latitude (aproximadamente $22^{\circ} 48^{\prime} \mathrm{S}$ ) mas em altitudes diferentes (Alumínio, $600 \mathrm{~m}$, e Campos do Jordão, 1500 m), no Estado de São Paulo. Como as flores abrem simultaneamente de manhã e perdem as pétalas ao pôr-do-sol, a interação com as abelhas só acontece durante a fotofase. As flores de L. elegans foram principalmente visitadas por abelhas, sendo as mais freqüentes: Tetraglossula anthracina (Michener, 1989) (Colletidae), Rhophitulus sp. (Andrenidae) e Pseudagapostemon spp. (Halictidae), consideradas abelhas especializadas em coletar pólen e néctar nessas flores, bem como a abelha generalista Apis mellifera Linnaeus, 1758 (Apidae). As abelhas especialistas estavam temporalmente ajustadas aos horários de abertura da flor. A abertura da flor ocorre principalmente de manhã, mas mostra variação circanual. T. anthracina aparece em ambas as áreas, mas somente entre dezembro e abril. O padrão 
de atividade anual das abelhas especialistas está sincronizado com a fenologia de L. elegans. Os ciclos fotoperiódicos e de temperatura são sugeridos como os principais sincronizadores de ambas, abelhas e plantas.

Palavras-chave: fotoperíodo, ritmo biológico, Tetraglossula, Pseudagapostemon, Rhophitulus.

\section{INTRODUCTION}

Studies concerning synchronization of annual activities among different organisms, such as beeflower relationships, are of special interest when the environmental conditions preceding both bee emergence and flower opening are considered (Linsley, 1978). Environmental factors influencing plant growth and maturation may be the same as those determining bee activity (Stephen et al., 1969).

The cyclical environmental changes associated with seasonal progression, in both temperate and tropical regions, are significant signalizing systems. All species, whether plant or animal, are sensitive to one or more specific environmental cycles. The annual photoperiodic (number of daylight $\mathrm{X}$ number of dark hours) and temperature cycles are important synchronization agents of the seasonal and circannual rhythms of a large number of species (Bünning, 1967; Beck, 1980; Saunders, 1982; Tauber et al., 1986; Lenga, 1991; Tauber \& Kyriacou, 2001). The combination of both photo- and thermoperiods undoubtedly has a powerful effect on the processes of ecological adaptation in a large variety of species (Beck, 1983; Tauber \& Kyriacou, 2001). Additionally, rainfall and drought cycles in the tropics may also influence the annual rhythms of the organisms there (Wolda \& Roubik, 1986; Hepburn \& Radloff, 1995).

Many studies concerning interactions between angiosperm flowers and pollinator bees have focused on their mutual synchronization during the year (Martins \& Antonini, 1994; Martins \& Borges, 1999; Minckley et al., 1999). This annual synchronization of activities among different organisms may in fact be driven by the same environmental and climatic factors, permitting an optimized encounter between them (Bünning, 1967).

The system composed of Ludwigia elegans flowers (Onagraceae) and their visitors is a notable example within biological rhythm study. The flowers of this species present a series of generalized characteristics attracting several types of visitors. However, they depend exclusively on bees for pollination. In studies of the interactions between bees and L. elegans flowers (Gimenes, 1997; Gimenes et al., 1993) in Ribeirão Preto (São Paulo State), it was observed that these plants flowered during the entire year although there was a flowering peak in March and April. Pollinator bees visited the flowers between December and April.

The present work seeks to analyze the annual rhythm of interaction between $L$. elegans flowers and their visitor bees in two different localities at different altitudes and under different climatic conditions, in the State of São Paulo, Brazil.

\section{MATERIAL AND METHODS}

Two different plant populations located at different altitudes in the State of São Paulo, Brazil, were chosen for study: Alumínio and Campos do Jordão.

Observations in Alumínio were performed in

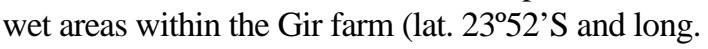
$47^{\circ} 2^{\prime} \mathrm{W}$, at altitudes from 600 to $832 \mathrm{~m}$ ). The region also contains scrub vegetation, forest, and reforested areas.

Observations in Campos do Jordão were performed along the margin of the Sapucai river, in boggy areas of the Campos do Jordão State Park (lat. $22^{\circ} 45^{\prime} \mathrm{S}$ and long. $45^{\circ} 30^{\prime} \mathrm{W}$, at $1500 \mathrm{~m}$ ) located on the Campos do Jordão plateau. The greater part of this region is covered by natural vegetation of Araucaria and Podocarpus forests (Seibert, 1975).

In both locations the study plots had approximately the same dimensions $(50 \times 20 \mathrm{~m})$. Most plants were approximately $1 \mathrm{~m}$ tall, reaching a maximum of $2 \mathrm{~m}$.

A detailed description of the chronobiologic protocol used in this study can be found in Marques \& Gimenes (1996).

Observations in Alumínio and Campos do Jordão were undertaken between November 89 and November 91. Each area was visited during three consecutive days on a bimonthly schedule. The flowering of $L$. elegans was quantified by counting 
the number of flowers present on the specimens observed. The number of nectar and pollen collecting visits to selected plants by the most frequent bee species were recorded during 15-minute periods every hour. Observation were begun before floral anthesis and continued until floral closing (7:00 to 18:00 h). There numbers were totaled monthly for these studies of annual bee activity.

Records of average monthly temperatures, relative humidity, and precipitation rates in Campos do Jordão and Alumínio were obtained from the Centro Regional de Metereologia e Climatologia de São Paulo. The method of Tubelis \& Nascimento (1986) was used to define the rainy season.

Specimens of L. elegans were deposited at the UEC Herbarium, Universidade Estadual de Campinas, and visitant bee specimens were deposited at the Museu de Zoologia, São Paulo.

A circular statistics method (Batschelet, 1980) was used to analyze the biological rhythms of both bee activity and flowering. Rayleigh tests were used to determine the significance of the data, and the Watson-Williams test to compare samples.

\section{RESULTS}

\section{Climatic aspects}

Due to their similarity in latitude, both study areas have similar photoperiods, while differing mainly in monthly average temperatures. Those registered in Campos do Jordão were approximately $6^{\circ} \mathrm{C}$ lower than those in Alumínio (Fig. 1).

The annual average temperature varied from 16 to $24^{\circ} \mathrm{C}$ in Alumínio, and 10 to $18^{\circ} \mathrm{C}$ in Campos do Jordão. The relative humidity varied from $68 \%$ to $78 \%$ in Alumínio, and $82 \%$ to $88 \%$ in Campos do Jordão. Both Alumínio and Campos do Jordão had a well defined rainy season. The hottest and rainiest months were December through March (summer).

In both locations there is a close relation between high temperatures and the long daylight hours of summer (photophase ranging from 13:34 to $12: 13$ hours), as well as between low temperatures and the short daylight hours of winter (photophase ranging from 11:39 to 11:02 hours).

\section{L. elegans}

A larger number of flowers of L. elegans were observed in Alumínio $(2,126)$ than in Campos do
Jordão (426). In Alumínio, L. elegans flowered from November to September, while in Campos do Jordão this species flowered from December to June. The Rayleigh test demonstrated the presence of a circannual rhythm of flowering for L. elegans in both locations. The mean-angle (corresponding to the flowering peak) in Alumínio was in February and March, while in Campos do Jordão it occurred in March (Table 1), months corresponding to the end of summer and the beginning of autumn and during which the average monthly temperature varied between 23 and $24^{\circ} \mathrm{C}$, while the photophase varied from 13:33 to 11:34 h (from long to short daylight).

Although there are differences between both the number of flowering-months and the absolute quantity of flowers observed in populations of $L$. elegans at Alumínio and Campos do Jordão, the Watson-Williams test demonstrated that both populations have their flowering peak in the same month (Tables 1 and 2).

During the hottest months of the year (November to April) L. elegans flowers opened between 8:00 and 9:30 a.m. in Alumínio, and around 9:00 a.m. in Campos do Jordão. On the coldest days (May to August), flowers opened after 10:30 a.m. in Alumínio, and around 12:00 in Campos do Jordão (Fig. 2), but generally only on days when temperatures reached more than $14^{\circ} \mathrm{C}$. It was observed that the opening of flowers in both areas followed a circadian pattern, occurring earlier during hotter months with longer daylight, and later in months with shorter, colder days. Floral opening occurred earlier in Alumínio than in Campos do Jordão, due to lower temperature at the latter site.

It was also observed that circadian rhythm of petal and stamen dropping in L. elegans flowers during the summer months occurred between 15:00 of 16:00 $\mathrm{h}$ in both areas. During the coldest months, flowers might wither at sunset or even last until the following day.

\section{Visitors}

In both study areas, L. elegans flowers were visited predominantly by bees. The most frequent visitor species were Tetraglossula anthracina (Michener, 1989) (Colletidae) and Rhophitulus sp. Ducke, 1907 (Andrenidae) in both Alumínio and Campos do Jordão, in addition to Pseudagapostemon spp. (Halictidae), but only in Alumínio. 
Both females and males of T. anthracina and Rhophitulus sp. visited flowers between December and April in both Alumínio and Campos do Jordão (Fig. 3), demonstrating a circannual rhythm as shown by the Rayleigh test. In Alumínio, the mean-angle (peak visiting) of both species corresponded to December (Table 1), a summer month in which the photophase is long and both temperatures and rainfall are high (Fig.
1). In Campos do Jordão the mean-angle of $T$. anthracina corresponded to March (females) and February (males). For Rhophitulus sp., the mean-angles corresponded to February (females) and December (males). Synchronization between the peak annual activity of $T$. anthracina and the flowering of L. elegans in Campos do Jordão was confirmed by the WatsonWilliams test (Table 2).

TABLE 1

Months with high activity of female and male Tetraglossula anthracina, Rhophitulus sp., Pseudagapostemon spp., and Apis mellifera, as well as peak flowering of Ludwigia elegans. Acrophase, medium vector (r), and angular deviation (S) in Alumínio (AL) and Campos do Jordão (CJ), from November 1989 to October 1991. Probability (p) evaluated by the Rayleigh test.

\begin{tabular}{|l|c|c|c|c|c|c|c|}
\hline \multicolumn{1}{|c|}{ Species } & Characteristic & Area & Acrophase $\left(^{\mathbf{o}}\right)$ & Month & r & S $\left(^{\mathbf{o}}\right)$ & p \\
\hline T. anthracina & Female & AL & 18.30 & Dec & 0.91 & 25 & $<0.05$ \\
\hline T. anthracina & Female & CJ & 99.15 & Mar & 0.87 & 30 & $<0.05$ \\
\hline T. anthracina & Male & CJ & 79.45 & Feb & 0.83 & 35 & $<0.05$ \\
\hline Rhophitulus sp. & Female & AL & 15.12 & Dec & 0.89 & 28 & $<0.05$ \\
\hline Rhophitulus sp. & Male & AL & 20.05 & Dec & 0.90 & 26 & $<0.05$ \\
\hline Rhophitulus sp. & Female & CJ & 72.40 & Feb & 0.78 & 40 & $<0.05$ \\
\hline Rhophitulus sp. & Male & CJ & 26.17 & Dec & 0.93 & 22 & $<0.05$ \\
\hline Pseudagap. spp. & Female & AL & 50.12 & Jan & 0.46 & 71 & $>0.05$ \\
\hline Pseudagap. spp. & Male & AL & 170.72 & May & 0.26 & 94 & $>0.05$ \\
\hline A. mellifera & Worker & AL & 90.84 & Mar & 0.78 & 40 & $<0.05$ \\
\hline A. mellifera & Worker & CJ & 115.97 & Mar/Apr & 0.97 & 14 & $<0.05$ \\
\hline L. elegans & Flower & AL & 85.34 & Feb/Mar & 0.79 & 39 & $<0.05$ \\
\hline L. elegans & Flower & CJ & 93.84 & Mar & 0.89 & 28 & $<0.05$ \\
\hline
\end{tabular}

TABLE 2

Comparison of the monthly foraging activities of Tetraglossula anthracina, Rhophitulus sp., Pseudagapostemon spp., and Apis mellifera as well as the flowering of L. elegans in Alumínio (AL) and Campos do Jordão (CJ), from November 1989 to October 1991. Significance determined by the Watson-Williams test $(\mathbf{R})(\mathbf{p}<0.05)$.

\begin{tabular}{|c|c|c|c|}
\hline Species 1 & Species 2 & $\mathbf{R}$ & $\mathbf{p}$ \\
\hline L. elegans - AL & L. elegans - CJ & 3.84 & $>0.05$ \\
\hline L. elegans - AL & T. anthracina $-\mathrm{AL}$ & 238.14 & $<0.05$ \\
\hline L. elegans-CJ & T. anthracina - CJ & 0.109 & $>0.05$ \\
\hline L. elegans - AL & Rhophitulus sp. - AL & 342.89 & $<0.05$ \\
\hline L. elegans - CJ & Rhophitulus sp. - CJ & 29.68 & $<0.05$ \\
\hline L. elegans - AL & A. mellifera-AL & 4.92 & $>0.05$ \\
\hline L. elegans - CJ & A. mellifera-CJ & 80.72 & $<0.05$ \\
\hline
\end{tabular}




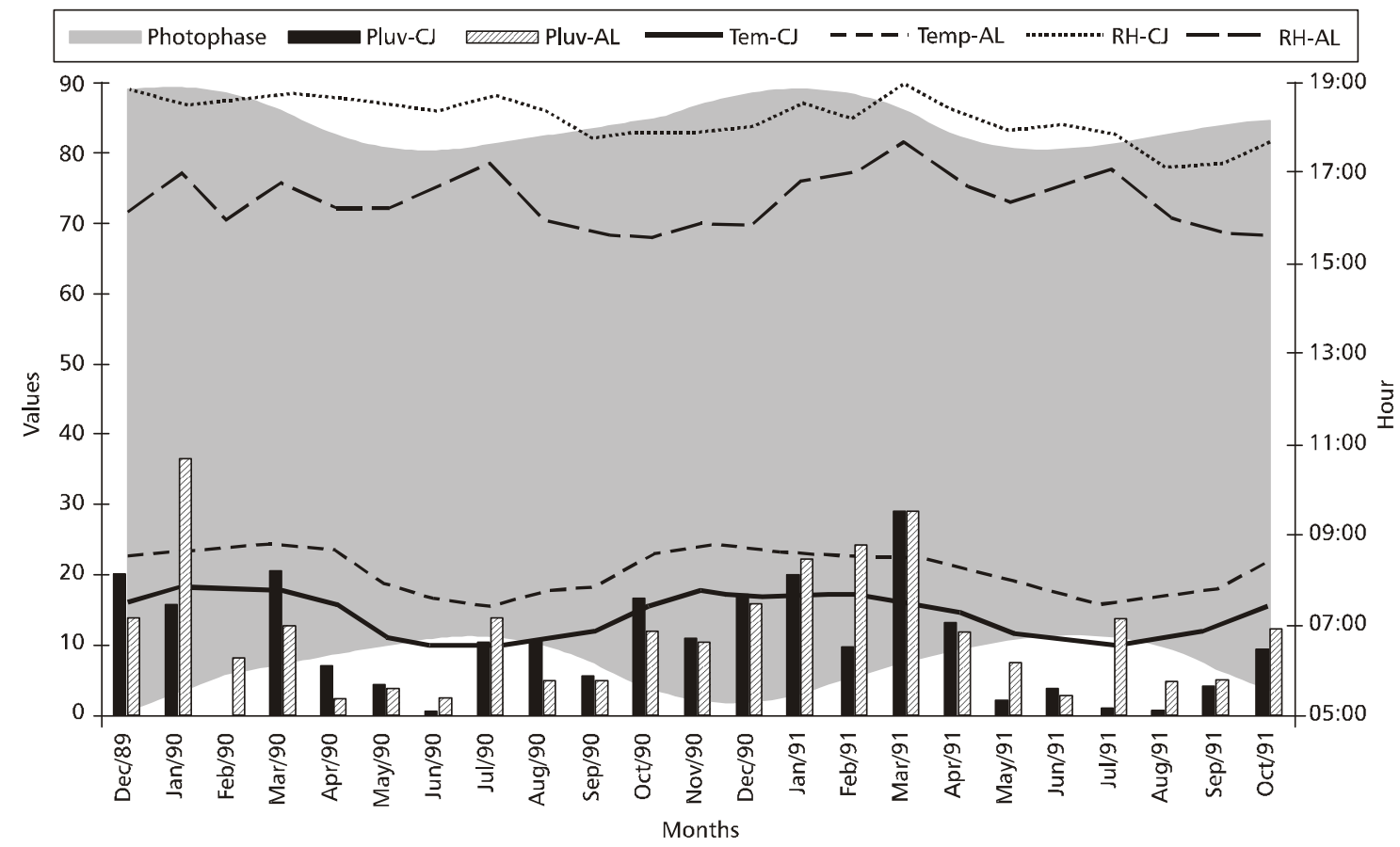

Fig. 1 - Temperature, relative humidity, precipitation, and photophase in Alumínio and Campos do Jordão, from December 89 to October 91.

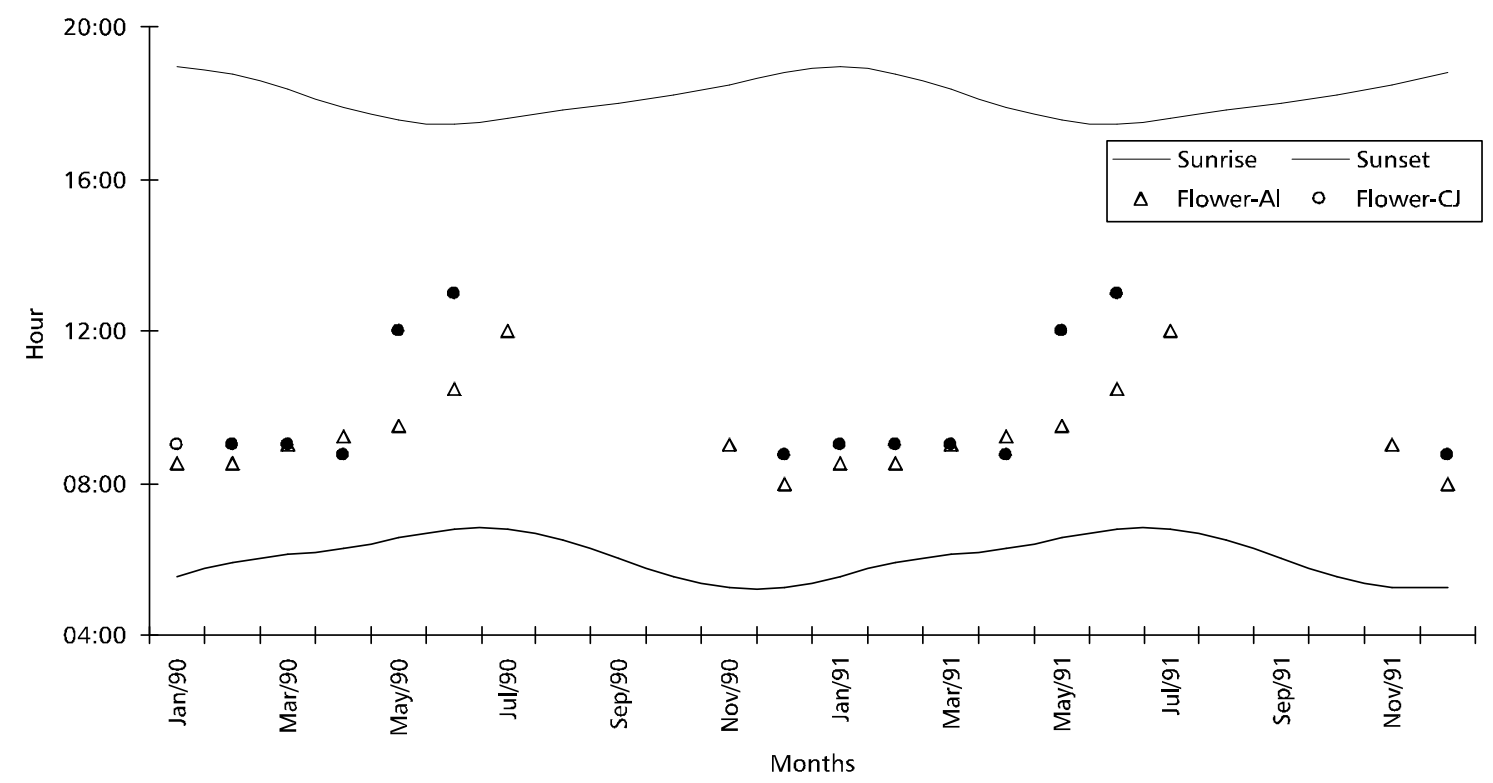

Fig. 2 - Time of flower opening and average monthly temperatures during the study in Alumínio and Campos do Jordão (January 90 to November 91 ). 


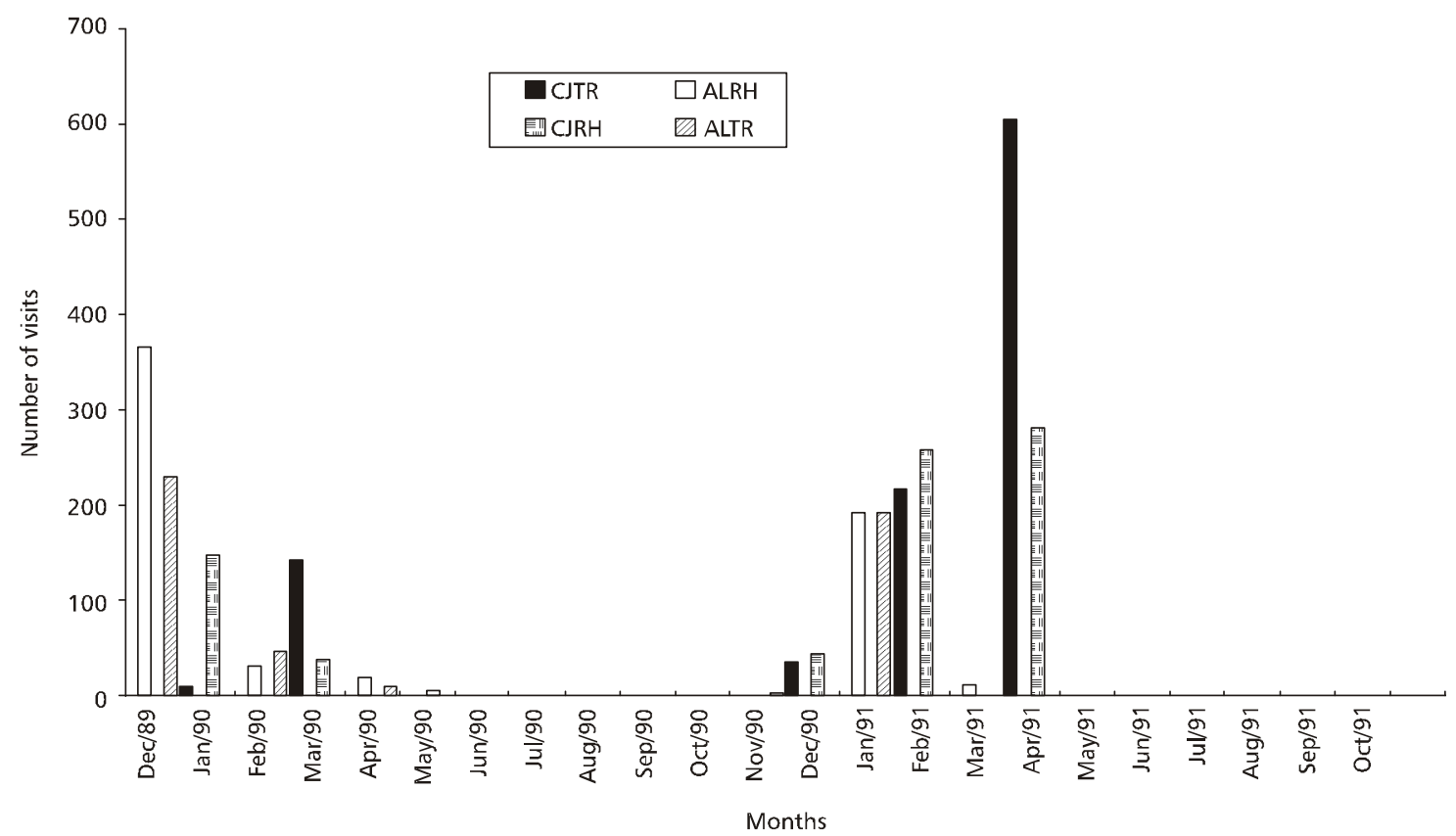

Fig. 3 - Number of visits of Tetraglossula anthracina (TR) and Rhophitulus sp. (RH) in Alumínio (AL) and Campos de Jordão (CJ) (December 89 to October 91).

By employing the latter test we determined that Rhophitulus sp. and T. anthracina females visited L. elegans flowers for pollen and nectar collecting during the same months in Aluminio, but during distinct months at the Campos de Jordão site (Table 3).

In Alumínio, two species of the genus Pseudagapostemon Schrottky, 1909 (Pseudagapostemon brasiliensis Cure 1989 and P. pruinosus Moure \& Sakagami, 1984), visited flowers during the entire flowering cycle of L. elegans. As these two species are very similar, we considered only the genus in totaling visits. These bees demonstrated a circannual rhythm, according to the Rayleigh test. Their mean-angles were in January (females) and May (males). The " $\mathrm{r}$ " (vector) values were very low, while the angular deviation pattern was very high (Table 1), indicating a very diffuse annual distribution of flower visitation.

Apis mellifera was observed constantly while L. elegans was in bloom in Alumínio, but only in March 1990, February 1991, and April 1991 in Campos do Jordão. This species demonstrated a circannual rhythm of nectar collection activity at
L. elegans flowers in both areas. In Alumínio the mean-angle was in March, while in Campos do Jordão it occurred in April (Table 1). There was synchronization between the peak of activity of $A$. mellifera and the flowering of L. elegans in Alumínio, as confirmed by the Watson-Williams test (Table 2).

\section{DISCUSSION}

\section{Ludwigia elegans}

Populations of L. elegans in Alumínio and Campos do Jordão demonstrated a circannual rhythm of flowering, with well-defined peaks in February and March. However, in Aluminio, the plants flowered for a longer period of time and produced larger numbers of flowers, possibly due to the higher temperatures there (Alumínio is located at a lower altitude than is Campos do Jordão). According to Bünning (1967), environmental temperature can influence the number of flowers observed in different populations (higher temperatures usually resulting in a greater number of flowers). 
TABLE 3

Comparison of the monthly foraging activities of Tetraglossula anthracina, Rhophitulus sp., Pseudagapostemon spp., and Apis mellifera on flowers of L. elegans during the year in Alumínio (AL) and Campos do Jordão (CJ), from November 1989 to October 1991. $F=$ female, $M=$ male. Significance determined by the Watson-Williams test $(\mathbf{R})(\mathbf{p}<0.05)$.

\begin{tabular}{|c|c|c|c|}
\hline Species 1 & Species 2 & $\mathbf{R}$ & $\mathbf{p}$ \\
\hline T. anthracina $-\mathrm{AL}-\mathrm{F}$ & T. anthracina $-\mathrm{CJ}-\mathrm{F}$ & 431.95 & $<0.05$ \\
\hline T. anthracina $-\mathrm{CJ}-\mathrm{F}$ & T. anthracina $-\mathrm{CJ}-\mathrm{M}$ & 20.80 & $<0.05$ \\
\hline T. anthracina $-\mathrm{AL}$ & Rhophitulus sp. - AL & 0.003 & $>0.05$ \\
\hline T. anthracina $-\mathrm{AL}$ & Pseudagapostemon spp. - AL & 30.91 & $<0.05$ \\
\hline T. anthracina $-\mathrm{AL}$ & A. mellifera $-\mathrm{AL}$ & 265.28 & $<0.05$ \\
\hline T. anthracina - CJ & Rhophitulus sp. - CJ & 42.91 & $<0.05$ \\
\hline Rhophitulus sp. - AL & Pseudagapostemon spp. - AL & 44.81 & $<0.05$ \\
\hline Rhophitulus sp. - AL & Rhophitulus sp. - CJ & 136.12 & $<0.05$ \\
\hline Rhophitulus sp. - CJ - F & Rhophitulus sp. - CJ - M & 22.12 & $<0.05$ \\
\hline Rhophitulus sp. - AL - M & Rhophitulus - sp. CJ - M & 0.468 & $>0.05$ \\
\hline Pseudagapostemon spp. - AL - F & Pseudagapostemon - $\mathrm{AL}-\mathrm{M}$ & 64.90 & $<0.05$ \\
\hline
\end{tabular}

Christy \& Sharitz (1980), working with Ludwigia leptocarpa (Nutt.) Hara, observed that these plants grew more and accumulated more biomass at higher temperatures than at lower temperatures $\left(22^{\circ} \mathrm{C}\right)$. Carpenter (1976) observed that populations of Metrosideros collina (Forster) (Myrtaceae) growing at different altitudes presented variations in their reproductive stages. Nonetheless, these different populations all showed the same flowering peak. Salisbury (1981) also noted the influence of altitude on many plant functions.

The effects of temperature can also be observed on the time of floral opening. Opening occurred earlier in Alumínio (a region with higher temperatures) and later in Campos do Jordão.

Additionally, flower opening occurred progressively later as the temperature became cooler. Opening shifted from early morning in the summer to around midday during the winter, presenting clear evidence of a link with the photoperiodic cycle at both study locations (Fig. 2).

The similar photoperiodic cycles of both Alumínio and Campos do Jordão could have been acting as a "zeitgeber" (synchronizer) for both populations, especially considering the synchrony observed in these two areas in terms of the peakflowering months for L. elegans. Many authors consider the photoperiod as the main environmental synchronizer for flowering rhythms. The photoperiodic environment depends on the latitude and although showing slight differences from year to year is, nevertheless, highly predictable and a powerful "zeitgeber" of circannual rhythms for most plants (Bünning, 1967; Salisbury, 1981; Koukkari, 1988; Carré, 2001). According to Bünning (1967), the difference of a single minute in the duration of the photophase can result in an increase or reduction of one full day in plant development.

In other locations, different species of Ludwigia can show flowering peaks in other months: Ludwigia suffruticosa (L.) Gomez flowered in winter (June) in Minas Gerais (Martins \& Antonini, 1994), while Jacobs et al. (1994) observed that Ludwigia peruviana (L.) Hara, recently introduced into Sidney, Australia, had its flowering peak at the beginning of autumn.

Differences observed between various populations of plants of genus Ludwigia may also be related to phenotypic plasticity (Kuiper, 1990).

\section{Visitors}

The most frequent bees visitors observed on flowers of L. elegans were represented by the genera Tetraglossula, Rhophitulus, and Pseudagapostemon, already identified as specialized visitors to the same flowers by other studies, and Tetraglossula was 
considered the most efficient pollinator (Gimenes, 1991, 1997; Gimenes et al., 1993, 1996). Although A. mellifera is a generalist visitor, it was considered a potential pollinator of L. elegans flowers (Gimenes, 1997).

Circannual rhythms of pollen and nectar collecting activity were observed for the most frequent bee visitors on $L$. elegans flowers. Their mean-angle was usually in the summer and beginning of autumn, most likely influenced by thermo- and photoperiodic cycles. Gimenes (1997) observed that collection activity of T. bigamica on L. elegans flowers in Ribeirão Preto (São Paulo) coincided closely with $T$. anthracina activity in Alumínio and Campos do Jordão (December to April).

According to the Watson-Williams test, there was a synchronization between the peak activity of $T$. anthracina and the peak flowering of L. elegans in Campos do Jordão. Reports of synchronized annual foraging activity of pollinators and peaks of plant flowering are common in the literature (Wolfe \& Barrett, 1988; Martins \& Antonini, 1994). Martins \& Antonini (1994), working on the biology of Diadasina distincta (Holmberg, 1903) (Anthophoridae), observed that the peak annual activity for this bee occurred in June, and was synchronized with the flowering peak of its main pollen source, L. suffruticosa.

The coincidental annual phases of activity of T. anthracina on L. elegans flowers in Alumínio and Campos do Jordão cannot be satisfactorily explained by temperature alone, as this parameter varied significantly between the two locations (Fig. 1). Additionally, the stages of activity of T. bigamica (Strand, 1910) in Ribeirão Preto (Gimenes, 1997), where temperatures were higher, were the same as those observed in Alumínio and Campos do Jordão. In this case, the photoperiodic cycle could be responsible for controlling the annual activities of bees, and which is likely the case for all three areas, with results similar to those observed on flowering in L. elegans, and with temperature generating the fine adjustments of the rhythm.

Pseudagapostemon spp visited L. elegans flowers in both Alumínio and Ribeirão Preto (Gimenes, 1997). Although a circannual rhythm has been detected in Pseudagapostemon spp. in Alumínio, it visited flowers throughout the year in a more diffuse way than either Rhophitulus sp. or $T$. anthracina. Additionally, Pseudagapostemon spp. was observed visiting other species of syntoptic Ludwigia in both locations. Although it has been considered a specialized visitor of $L$. elegans flowers, the small size of this bee does not allow it to efficiently pollinate these flowers (Gimenes, 1997). As this genus is generally associated with Ludwigia flowers (Sazima \& Santos, 1982) and occurs at higher altitudes (Silveira \& Cure, 1993), its absence in Campos do Jordão is difficult to explain.

A. mellifera visited L. elegans flowers very frequently, and its role as a potential pollinator has been already discussed (Gimenes, 1997). Nonetheless, its synchronization to the flowering peak of L. elegans must be analyzed within the context of it being a highly eusocial species and a generalized visitant, with a very efficient communication system between the workers (Seeley, 1985) and the floral facultative constancy (Free, 1963). These characteristics probably resulted in the great number of visits during the months of peak flowering.

We conclude that the coincidence of the visitation peaks of the most frequent bees and potential pollinators with the peak flowering of $L$. elegans during the year were probably influenced by both thermo- and photoperiodic cycles, thus guaranteeing a sure resource supply for the bees and successful seed production for the plants.

Acknowledgments - The author wishes to thank M. D. Marques for her suggestions, M. A. C. Lopes for both helping during field observations and preparing the figures; J. S. Moure, L. Ruz, G. A. Melo, and D. A. Yanega for bee identifications, and Elza M. Zardini for plant identifications. Thanks also to the administration of the Campos do Jordão State Park and the Gir farm for their support during the field work phase. Financial support received from CAPES was greatly appreciated.

\section{REFERENCES}

BATSCHELET, E., 1980, Circular statistics in biology. Academic Press, London, 371p.

BECK, S. D., 1980, Insect photoperiodism. 2. ed., Academic Press, New York, 387p.

BECK, S. D., 1983, Insect thermoperiodism. A. Rev. Ent., 28: 91-108.

BÜNNING, E., 1967, The physiological clock. 2. ed., SpringerVerlag, New York, 167p.

CARPENTER, F. L., 1976, Plant-pollinator interactions in Hawaii: pollination energetics of Metrosideros collina (Myrtaceae). Ecology, 57: 1125-1144.

CARRÉ, I. A., 2001, Day-length perception and the photoperiodic regulation of flowering in Arabidopsis. $J$. Biol. Rhythms, 16(4): 415-423. 
CHRISTY, E. J. \& SHARITZ, R. R., 1980, Characteristics of three populations of a swamp annual under different temperature regimes. Ecology, 61(3): 454-460.

FREE, J. B., 1963, The flower constancy of honeybees. J. Anim. Ecol., 32(1): 119-131.

GIMENES, M., 1991, Some morphological adaptations in bees (Hymenoptera, Apoidea) for collecting pollen from Ludwigia elegans (Onagraceae). Revta. Bras. Ent., 35(2): 414-422.

GIMENES, M., 1997, Pollinating bees and other visitors of Ludwigia elegans (Onagraceae) flowers at a tropical site in Brazil. Stud. Neotrop. Fauna Environ., 32(2): 81-88.

GIMENES, M., BENEDITO-SILVA, A. A. \& MARQUES, M. D., 1993, Chronobiologic aspects of a coadaptive process: The interaction of Ludwigia elegans flowers and its more frequent bee visitors. Chronobiol. Internat., 10(1): 20-30.

GIMENES, M., BENEDITO-SILVA, A. A. \& MARQUES M. D., 1996, Circadian rhythms of pollen and nectar collection by bees on the flowers of Ludwigia elegans. Biol. Rhythm Res., 27: 281-290.

HEPBURN, H. R. \& RADLOFF, S. E., 1995, First approximation to a phenology of the honeybees Apis mellifera and flora of Africa. Oecologia, 101(3): 265-273.

JACOBS, S. W. L., PERRETT, F., SAINTY, G. R., BROWMER, K. H. \& JACOBS, B. J., 1994, Ludwigia peruviana (Onagraceae) in the botany wetlands near Sydney, Australia. Aust. J. Mar. Freshwater Res., 45: 1481-1490.

KOUKKARI, W. L., 1988, The broad spectrum of plant rhythms. Adv. Biosci., 73: 31-41.

KUIPER, P. J. C., 1990, Analysis of phenotypic responses of plants to changes in the environment in terms of stress and adaptation. Acta Bot. Neerl., 39(3): 217-227.

LENGA, A., THIBEAUDEAU, C. \& HUIGNARD, J., 1991, Influence of thermoperiod and photoperiod on reproductive diapause in Bruchidius atrolineatus (Pic) (Coleoptera, Bruchidae). Physiol. Ent., 16: 295-303.

LINSLEY, E. G., 1978, Temporal patterns of flower visitation by solitary bees, with particular reference to the southwestern United States. J. Kansas Ent. Soc., 51(4): 531-546.

MARQUES, M. D. \& GIMENES, M., 1996, Control of environmental variables in a field study using a chronobiological protocol. Brazilian J. Med. Biol. Res., 29: 141-145.

MARTINS, R. P. \& ANTONINI, Y., 1994, The biology of Diadasina distincta (Holmberg,1903) (Hymenoptera: Anthophoridae). Proc. Ent. Soc. Wash., 96(3): 553-560.
MARTINS, R. P. \& BORGES, J. C., 1999, Use of Ludwigia (Onagraceae) pollen by a specialist bee, Diadasina distincta (Hymenoptera: Apidae), at a nesting site in Southeastern Brazil. Biotropica, 31(3): 530-534.

MINCKLEY, R. L., CANE, J. H., KERVIN, L. \& ROULSTON, T. H., 1999, Spatial predictability and resource specialization of bees (Hymenoptera: Apoidea) at a superabundant, widespread resource. Biol. J. Limn. Soc., 67(1): 119-147.

SALISBURY, F. B., 1981, Responses to photoperiod. In: A. Pirson, Encyclopedia of Plant Physiology. New Series Berlin, Springer-Verlag, pp. 135-167.

SAUNDERS, D. S., 1982, Insect clocks. 2. ed. Pergamon Press, Oxford, 409p.

SAZIMA, M. \& SANTOS, J. U. M. dos, 1982, Biologia floral e insetos visitantes de Ludwigia sericea (Onagraceae). Bolm. Mus. para. E. Goeldi, Série Botânica, 54: 1-12.

SEELEY, T. D. 1985. Honeybee ecology. A study of adaptation in social life. Princeton University Press, Princeton, NJ, $201 \mathrm{p}$.

SEIBERT, P., 1975, Plano de manejo do Parque Estadual de Campos do Jordão. Bol. Téc. IF São Paulo, 19: 1-153.

SILVEIRA, F. A. \& CURE, J. R., 1993, High-altitude bee fauna of Southeastern Brazil: Implications for Biogeographic patterns (Hymenoptera:Apoidea). Stud. Neotrop. Fauna. Envir., 28(1): 47-55.

STEPHEN, W. P., BOHART, G. E. \& TORCHIO, P. F., 1969, The biology and external morphology of bees. Agricultural Experimental Station, Oregon State University, Oregon, 140p.

TAUBER, M. J., TAUBER, C. A. \& MASAKI, S., 1986, Seasonal adaptations of insects. Oxford University Press, New York, Oxford, 411p.

TAUBER, E. \& KYRIACOU, B. P., 2001, Insect photoperiodism and circadian clocks: models and mechanisms. J. Biol. Rhythms, 16(4): 381-390.

TUBELIS, A. \& NASCIMENTO, F. J. L. do, 1986, Meteorologia descritiva. Nobel, São Paulo, 373p.

WOLDA, H. \& ROUBIK, D. W., 1986, Nocturnal bee abundance and seasonal bee activity in a Panamanian forest. Ecology, 67(2): 426-433.

WOLFE, L. M. \& BARRETT, S. C. H., 1988, Temporal changes in the pollinator fauna of tristylous Pontederia cordata, an aquatic plant. Can. J. Zool., 66: 1421-1424. 